\title{
An Examination of Senior High School Social Studies Teachers' Instructional Practices in the West Mamprusi Municipality
}

\author{
Ibrahim Abudulai \\ Social Science Department, Gambaga College of Education, Gambaga, Ghana \\ Email: iabudulai76@yahoo.com
}

How to cite this paper: Abudulai, I. (2020) An Examination of Senior High School Social Studies Teachers' Instructional Practices in the West Mamprusi Municipality. Open Access Library Journal, 7: e6186.

https://doi.org/10.4236/oalib.1106186

Received: February 25, 2020

Accepted: April 5, 2020

Published: April 8, 2020

Copyright $\odot 2020$ by author(s) and Open Access Library Inc.

This work is licensed under the Creative Commons Attribution International License (CC BY 4.0).

http://creativecommons.org/licenses/by/4.0/

(c) (i) Open Access

\begin{abstract}
The study sought to examine the instructional techniques used by Senior High School (SHS) Social Studies teachers in the West Mamprusi Municipality of the North-East Region of Ghana. A sample of thirty-two (32) teachers was selected for the study using the simple random and convenient sampling techniques. As a qualitative study, an open-ended (unstructured) interview guide and observational (direct) guide were designed to elicit information from the respondents. The study focused on the teachers' knowledge of Social Studies general objectives, knowledge of Social Studies instructional techniques and how the teachers use these instructional techniques to teach the subject in the Senior High School to achieve the general objectives of the subject. The study revealed among other things that: 1) teachers' knowledge of the general objectives of Social Studies fell short of the expectation of effective Social Studies teachers, specially trained to teach the subject; 2) teachers also had limited knowledge of the instructional techniques of teaching Social Studies and 3) lessons observed were mostly done by the use of lecture, discussion, and questions and answers techniques; projects, simulations and games, problem-solving, inquiry and Fieldtrip techniques were virtually absent in the teaching of Social Studies. Based on the findings of the study, it is recommended among others that: recruitments of teachers by the Ghana Education Service (GES) to teach Social Studies should be strictly based on professional qualifications in the subject.
\end{abstract}

\section{Subject Areas}

Social Sciences \& Humanities

\section{Keywords}

Instructional Techniques, Objectives, In-Field Teachers and Out-of-Field Teachers 


\section{Introduction}

The introduction of Social Studies the world over was usually triggered by the quest to use the subject to solve contemporary persistent societal challenges. A close study of the historical development of Social Studies taught in the United States of America (USA) and Britain has revealed that it has a great impact on the attitudes of citizens [1] when African nations achieved independence in the late 1950s and 1960s they were bedeviled with the same challenges as America and Britain [2] African nations, and therefore, sought ways to change inherited educational systems to make them more suitable to the needs of the new nations of which Ghana is part. In recent times, Ghana has been faced with many challenges that threaten the very fabric of society and prevent national development. Moral decadence, apathy, blatant disregard for established authority, stereotypical get-it-easy attitude, careless driving on our roads, cyber fraud just to mention but a few are all challenges Ghana as a nation is bedeviled with [3] Social Studies became a core subject in the Senior High School curriculum in Ghana with the implementation of the educational reforms of 1987, that is, over three decades ago. Since then it has remained quite uncertain if the subject has achieved or is achieving its objective of inculcating effective citizenship in the learners judging from the above social vices. Education for citizenship has emerged as a significant area of primary, secondary and early education curriculum throughout the world [4]. Citizenship education is the pivot for the development of skills, values, knowledge, and understanding required to become active and responsible citizens in the country. To achieve this, it calls for the knowledge and use of varied instructional techniques in the teaching of Social Studies to achieve its intended objectives.

Social Studies lessons are supposed to be engaging; it means they should be full of activities that help learners to acquire the values and attitudes needed to function well in society. In selecting the appropriate instructional techniques, teachers need to put it at the back of their minds to select those that will affect the attitudes, values, and skills of learners positively which is the focus of Social Studies education or citizenship education. Because of this, there is the need to take a critical look at how Social Studies is taught in our schools especially Senior High Schools. The achievement of the general objectives of the subject depends on teachers' knowledge and practical application of its varied instructional techniques in the classroom. It is on these bases that this research sought to examine the instructional techniques used by Senior High School Social Studies teachers in the West Mamprusi Municipality of North-East Region of Ghana to achieve the general objectives of the subject.

\section{Statement of the Problem}

Social Studies became a core subject in the Senior High School curriculum in Ghana to change attitudes and values of learners to enable them to become well-informed citizens capable of contributing positively towards the develop- 
ment of society [3]. But, it is still quite uncertain whether the subject has achieved or is achieving its objective of inculcating effective citizenship in the learners who are taught Social Studies judging from how Ghanaian cherished values and attitudinal standards are falling completely. There seems to be a gap between what Social Studies teachers teach in the classroom and behaviour expected of learners in society. Although much has been said on the varied instructional techniques available to Social Studies teachers to use to achieve the general objectives of the subject [5] [6] [7], very little is known about how Senior High Schools teachers' in West Mamprusi Municipality of North-East Region of Ghana use these appropriate instructional techniques to achieve the general objectives of Social Studies. It seems the knowledge and use of instructional techniques by SHS Social Studies teachers in lesson delivery are at variance with the objectives of the subject which this research sought to examine.

\section{Research Questions}

The study was guided by the following research questions:

1) What do Social Studies teachers of West Mamprusi Municipality know about the general objectives of the subject?

2) What do teachers of Social Studies in the West Mamprusi Municipality know about Social Studies instructional techniques?

3) How do Social Studies teachers in the West Mamprusi Municipality of North-East Region of Ghana use instructional techniques to achieve the general objectives of the subject?

\section{Review of Literature}

\subsection{General Objectives of the Social Studies Curriculum}

Social Studies as a subject has been defined differently by different authorities and authors [8] [9], Despite the varied definitions of Social Studies, these definitions can be grouped into three broad categories; first, Social Studies is seen as an approach to the teaching of the social sciences; second, Social Studies as an amalgamation of social sciences and third, Social Studies is seen as citizenship education. [7] explained that the overall instructional objective of Social Studies is to prepare learners for a changing world; this is necessitated by the fast-growing population of the world with its emerging challenges. Social Studies is a subject that provides learners with the right knowledge, skills, attitudes, and understanding that are needed in both their public and personal endeavours. These skills, knowledge, and attitudes are very relevant in addressing personal and societal challenges which is one of the major objectives of Social Studies. [9] asserted that the purpose of Social Studies is to prepare learners to be good citizens, to teach learners how to think and pass on the cultural heritage to the younger generation. [9] might be right; because it must be realized that Social Studies does not only pass on the cultural heritage to the next generation but inculcates the relevant aspect of culture to the younger generations. [6] men- 
tioned that the proponents of Social Studies as citizenship education came up with the following as the general objectives of teaching the subject:

1) Adaptation of the learner to the changing environment. The learning of Social Studies should equip learners with relevant knowledge, positive attitudes, values, and skills to adjust to his or her changing society.

2) Development of national consciousness and unity. This objective aims at creating awareness among learners that notwithstanding the diverse ethnic groups that are found in Ghana, we are all one people belonging to the same nation with a common destiny.

3) Development of positive attitudes, values, and skills. This objective would inculcate positive attitudes into learners so that they would become good citizens who would join hands in moving the nation forward.

4) Development of good citizens who are willing and capable to contribute towards national development. This objective would inculcate into learners the need to eschew all forms of negative attitudes towards work such as absenteeism, pilfering among others and rather work conscientiously and contribute their widow's mite towards national development.

5) Ability to make rational decisions in solving problems. This objective would make learners reflective citizens-citizens who are capable of channeling the knowledge acquired into action in the form of problem-solving and decision making.

Social Studies seems not to have "universal objectives." This view is supported by [6] when they said that all the objectives of different scholars writing point to the same thing, that is, training for citizenship. For Social Studies to be well taught in schools in Ghana to achieve the general objectives, Social Studies teachers need to have adequate knowledge of the objectives of the subject and how to properly apply them in the classroom.

\subsection{Social Studies Teachers' Knowledge of Instructional Techniques and Methods}

The use of the words "techniques" and "methods" of Social Studies are sometimes used interchangeably as if they are synonyms. "Method" of teaching refers to everything the teacher does in the classroom in the course of a lesson delivery [6]. A method of teaching is the systematic way by which teachers go about their teaching. There are two methods of teaching; thus, teacher transmission or presentation method where the teachers' approach to lesson delivery is to tell learners what they need to know about the topic. The second method is the discovery, inquiring or problem-solving where the teacher does not tell learners what they need to know but rather allows or challenge learners to examine, investigate and explore an issue or challenge. A "technique" on the other hand, refers to any activity teachers ask their learners to do during lesson delivery. For example, role-play and debate [6]. Technique can be seen as specific kinds of exercise, task or activities used by teachers and learners to achieve instructional 
objectives [10], Cognitive (didactic) development instructional technique has objectives that aim at developing the intellectual skills of the learner; the cognitive development technique improves comprehension, analysis, synthesis, and evaluation of concepts or information. An example in mind is the lecture technique. The affective (phyletic) development technique emphasizes the development of interest, dispositions, attitudes, and values of learners. In trying to develop a learner's appreciation and skills of adequate adjustment, the affective or phyletic techniques are most valuable. Educational tours, group or cooperative learning, role play, dramatization are some of the good examples of the affective technique. Finally, the psychomotor (heuristic) development techniques are activity-based geared towards the development of learners' motor skills. Good examples of instructional techniques that can be used to achieve this domain are demonstration, role play, and game or simulations. The achievement of the general objectives of Social Studies relies on the kind of techniques of teaching and learning selected and used by the teachers who are given the mandate to directly implement the curriculum.

A good instructional technique motivates learners by engaging them in the learning process, stimulate thinking and reasoning by urging learners to reflect on what they are learning, why they are learning it and aim at achieving desired outcomes in the learner and of the teacher in class [6] [7] stated that the difference between creative and uninspired teaching is determined by the techniques teachers use in teaching to changing the attitudes, values, knowledge, and skills of learners. Teachers should use instructional techniques of Social Studies that can easily affect the achievement of its objectives. Teaching Social Studies in the classroom involves learners' use of the senses; thus, the eyes, ears, hands, muscles and the whole body in the learning process [11]. This suggests that the teaching and learning of Social Studies should not only be in the classroom but should also be planned and taken outside the classroom. A teacher whose instructions are full of lecture, reading and writing in Social Studies does not inspire learners to learn. The use of these instructions by the teacher, tend to deny learners the opportunity of a variety of instructional techniques. Learners have more interest in the topic when a variety of instructional techniques are used [12] [13] [14] outlined the following as techniques in Social Studies; lecture, discussion, simulation, role-play, fieldwork, team teaching, drama among others. Depending on the topic and age of learners if the above techniques are used effectively in the classroom by teachers it can lead to the achievement of the general objectives of the subject.

\subsection{How Social Studies Teachers Use Instructional Techniques to Achieve the General Objectives of the Subject}

Teachers are known as informed or educated actors who are consciously exploring the acts to transmit knowledge, skills, attitudes or values through systematic and orderly procedures. To continue to be effective in this regard calls on 
teachers to appropriately select and use instructional techniques in the classroom where there is teacher-learner interaction. A teacher does not only stand in front of the class and claims to be an effective teacher but how he or she uses the instructional techniques and the objectives he or she wants to achieve at the end of the lesson must be seriously considered. [15] opined that the effectiveness of the teacher in the classroom depends on the appropriateness of the stuff imparted, his or her understanding of the instructional techniques. These techniques include dramatization, discussion, role-play, debate, and simulation, concept mapping and anticipated guides among others. [16] "Using these teaching techniques are considered by many as the best practices and numerous studies also concluded positively about the use of these instructional techniques". Social Studies is a subject that tries to address challenges in our society; therefore in lesson delivery, teachers should be very clear in their minds about how the topic poses a challenge to the individual and the nation as a whole. For instance, in teaching a topic such as "National Independence and Self-reliance", the teacher should realize that the topic is not calling on him or her to merely draw learners attention to the challenges of national independence and self-reliance; hence the hardship of the economy; but to let learners identify the relationship between independence and increase in production in the nation. The teacher should not make learners believe that independence was an end in itself and was a time for leaders to amass wealth for themselves and Ghanaians to adopt a laissez-faire attitude to work in the nation. The focus of this topic should be on how skills can be developed in learners to enable them to have foresight into our challenges as a nation and contribute their quota in solving them.

In using games or simulation as a technique to teach in class, the Social Studies teacher needs to identify a problem of a topic or unit. The teacher then discusses the simulation issue with the learners as well as the rules for the simulation or game with the learners specifying and assigning roles to them. The resources and constraints of the simulation and game are to be outlined for learners' consumption. Finally, the teacher debriefs the learners because learners sometimes tend to focus on "who won" rather than what the process or procedure was and the learning that has taken place. In teaching learners in Social Studies class to acquire values in the society, for example, learners are allowed to examine situations created by value conflicts. This conflict situation calls for the learner's examination and appropriate judgment. In teaching for values teachers can create a scenario to put learners in a state of dilemma. For instance, the teacher can say this "when you were a child it was your uncle who sent you to school because your father was poor, and that your mother and aunt took care of you. Now as a teacher you are expected to be responsible for the upkeep of your wife and children. At the same time, you are being called upon to support, your grandmother and other relations. But your salary is inadequate and, in your estimation, cannot meet your needs." With this scenario, the teacher can probe learners more by asking them these questions: 
1) Would you reduce your responsibility to your wife and children only? If yes why?

2) Do you think that you have to support members of your extended family when your salary is low?

3) In your view scanty salary, would you take school fees money to pay the medical bills of your eighty-year-old aunt?

A Social Studies teacher who takes his/her learners through this process will be equipping them with tools that they can use in achieving objectives of Social Studies and citizenship competencies. In this scenario, learners will learn how to apply knowledge to solve their challenges. They can also use the knowledge to come out with appropriate conclusions about issues and make a valid judgment. Another technique Social Studies teacher can also use is a problem-solving technique which can also lead to the attainment of the objectives of the subject. [17] problem-solving is explained as a planned attack upon a difficulty to find a solution. He added that it is a method in which a person uses his/ her ability to solve challenges confronting him/her to enable him/her to have control over his or her activities and environment. Using the problem-solving technique in teaching Social Studies requires a teacher who can see challenges clearly; the ability to analyze and the faculty to synthesize and draw conclusions with accuracy. Social Studies can, therefore, be seen as a subject that has varied instructional techniques that teachers can use to attain the general objectives of the subject. But this can be possible if teachers who are to use them are well trained in the subject and have the objectives of the subject at the back of their minds.

\section{Methodology}

\subsection{Research Approach}

The researcher adopted plans and procedures that started from broad assumptions to specific methods of data collection and analysis as stipulated by [18]. In line with Creswell, the researcher adopted the qualitative research approach and also on the bases of the nature of the research problem or issue being addressed, the researchers' personal experiences, and the audiences for the study. The choice of this approach was to enable the researcher make an in-depth study of the instructional techniques Social Studies teachers employ to achieve the general objectives of the subject through interviews and observations in order to improve the quality of teaching in Social Studies in the classroom. A qualitative approach is associated with constructivist or social constructivist/ interpretivist approaches [19].

\subsection{Research Design}

The research design refers to the overall strategy that the researcher chooses to integrate the different components of the study coherently and logically to effectively address a research problem [20]. In line with this; a descriptive case study was adopted. 


\subsection{The Population of the Study}

The population of a study refers to the group to whom the researcher would like to generalize the results of the study [21] [22] [23] [24]. The population for this study, therefore, included all Senior High Schools Social Studies teachers both in-field and out-of-field in the North-East Region of Ghana. The target population in this study consisted of all Social Studies teachers in the West Mamprusi Municipality. The sample size for the study was thirty-two (32) Social Studies teachers teaching the subject from six (6) Senior High Schools within the Municipality. Sampling method such as simple random and convenient sampling techniques was employed to select the sample of schools and teachers for the study. As a qualitative research, the study tried to describe and explain teachers' experiences, behaviours, interactions and social contexts without the use of statistical procedures or quantification [25]. Table 1 below shows the number of schools and respondents (teachers) selected for the study.

Table 1 indicates the number of Social Studies teachers and schools employed for the study. Thirty-two teachers were selected from the six (6) Senior High Schools within the West Mamprusi Municipality in the North-East Region of Ghana.

\subsection{Sample and Sampling Techniques}

The worth of any educational research findings relies on the extent to which the sample reflects or represents the target population [26] [27]. Six (6) schools were considered for the study. This is because they are the only Senior High Schools in the West Mamprusi Municipality and are a bit closer to each other as compared to other Municipalities and Districts in the Region. This was to make the researcher's study relatively easy and faster. Again, teachers who were willing and able to be interviewed and observed were thirty-two (32) who comprised both in-field and out-of-field teachers. Simple random and convenient sampling techniques were used to select teachers for the study. Thus, no special considerations were taken for the selection of the teachers teaching Social Studies. It was based on teachers who were willing and ready to be interviewed and observed. Ten (10) teachers were selected to be observed, and were among the thirty-two (32) teachers for the study; thus, two teachers each from five schools.

Table 1. Name of schools and number of teachers.

\begin{tabular}{cc}
\hline School & Number of Teachers (Respondents) \\
\hline WULSEC & 9 \\
WALSETECH & 10 \\
WAVTI & 8 \\
ST. PAUL'S & 2 \\
JANTECH & 0 \\
EXELLENT SHS & 3 \\
Total & 32 \\
\hline
\end{tabular}




\subsection{Instruments for Data Collection}

To gather the most comprehensive, credible and dependable data pertinent to the research questions, two data collection instruments were used. These were the interview guide and observation guides for teachers. According to [28], "An interview is an extendable conversation between partners that aims at having in-depth information about a certain topic or subject, and through which a phenomenon could be interpreted in terms of the meanings interviewees bring to it". The researcher therefore, adopted open-ended (unstructured) interview so as not to suggest certain kinds of answers to teachers and to allow unusual responses to be derived so that both eminent and immanent themes were explored. Interview guide was therefore, adopted by the researcher as a tool because it facilitated the search for direct explanations of how Social Studies is taught at the selected Senior High Schools using the subject instructional techniques. Also, to [29] observation consists of collecting impressions of the surrounding worlds through all important human faculties such as hearing, seeing, smelling and touching. For [29] this enables researchers to access those aspects of social setting that may not be visible to the general public; thus, those backstage activities that the public does not generally see. Observations give researchers opportunity to provide rich, detailed descriptions and interpretation of the social setting in the field of study. The researcher therefore, adopted direct and overt observation. Direct observation is often defined as observing events or behaviors as they occur without altering the environment in which the events occur [30]. And overt observation requires the researcher to be open about his/her intentions and requires the researcher to inform the participants in order to ensure that they are aware of what is happening [31].

\subsection{Data Analysis}

Qualitative data analysis can be described as the process of making sense from research participants' views and opinions of situations, corresponding patterns, themes, categories and regular similarities [32]. For this reason, descriptive and interpretive techniques were used to analyze the data based on the themes arrived at in the data collection. The themes were related to the research questions and interpreted on the number of issues raised by respondents.

\section{Findings and Discussions}

\subsection{General Findings from Interview}

Table 2 showed that there are teachers with diverse educational backgrounds, qualifications, and experiences teaching Social Studies in Senior High Schools in the West Mamprusi Municipality of North-East Region. It was realized from Table 2 that twenty-two (22) of the teachers are not Social Studies professionals (Out-of-field) but teaching Social Studies. There were equally ten (10) of the teachers who were professionals (In-field) trained either from the University of Education, Winneba (UEW) and University of Cape Coast (UCC) teaching So- 
cial Studies. This implies that teachers who have not gotten in-depth knowledge of the instructional techniques in Social Studies were assigned to teach the subject. This is a crucial factor because highly qualified teachers may become highly unqualified if they are assigned to teach subjects for which they have little background thereby affecting their ability to teach to achieve the objective of the subject they teach [33]. It was also realized from Table 3 that all the thirty-two (32) teachers sampled for the study possess the minimum academic qualification to teach at the Senior High School which is the degree. Table 4 also indicates that twenty-five (25) teachers have never attended any in-service courses for teaching Social Studies. The phenomenon of out-of-field teachers teaching Social Studies from these findings seems to be a threat to the achievement of the objectives of Social Studies [34].

\subsection{General Findings from Observation}

The results showed that out of the Ten (10) teachers sampled for observation, none of them was observed making use of instructional technique(s) such as project work, simulations/games, field trips, inquiry or corporate learning, problem-solving techniques, among others that could develop learners' attitudes, values, and skills Social Studies tries inculcating into learners. Teachers were also observed intermittently giving notes and using textbooks even though the topics they were teaching demanded the use of instructional techniques such as group discussion, projects, inquiry, among others. Again, it was observed that all the Ten (10) Social Studies teachers observed did not evaluate their learners before concluding their lessons and did not also teach their topics to reflect in the real-life situations of the learners. This is because they were not relating what they were teaching in the classroom to similar current happenings in society. It was further observed that teachers teaching Social Studies paid little attention to the instructional objectives of Social Studies. This could be the reflection of the findings from the interview conducted where twenty-five (25) of the teachers could not vividly mention more than one of the objectives of Social Studies; only seven (7) teachers could say that Social Studies helps to train learners to fit well into society and relate well with people in society. Again, the observation revealed that teachers presented their lessons through the use of lecture as their technique with the dictation of notes for learners to copy. This issue is at variance with the techniques teachers mentioned during the interview session that they used in their teaching.

Table 2. Professional Qualification of teachers teaching Social studies in SHS in West Mamprusi Municipality.

\begin{tabular}{cc}
\hline Professional Qualification & Number of Teachers \\
\hline Out-of-field Teachers & 22 \\
In-field Teachers & 10 \\
Total & 32 \\
\hline
\end{tabular}

Source: Field data, 2019. 
Table 3. Academic Qualification of teachers teaching Social studies in SHS in West Mamprusi Municipality.

\begin{tabular}{cc}
\hline Academic Qualification (Degree) & Number of Teachers \\
\hline B.ED Social Studies & 8 \\
B.ED Geography & 10 \\
B.ED Economics & 11 \\
BA History & 2 \\
BA Sociology & 1 \\
Total & 32 \\
\hline
\end{tabular}

Source: Field data, 2019.

Table 4. In-service training attended by teacher teaching Social Studies in SHS in West Mamprusi Municipality.

\begin{tabular}{cc}
\hline In-service Training & Number of Teachers \\
\hline Attended & 7 \\
Not attended & 25 \\
Total & 32 \\
\hline
\end{tabular}

Source: Field data, 2019.

\subsection{What Are the Knowledge of Teachers of the General Objectives of Social Studies in the West Mamprusi Municipality of North-East Region of Ghana?}

The knowledge of the objectives of Social Studies among Social Studies teachers was not with much difference. Twenty-five (25) teachers could not clearly state the general objectives of Social Studies; except three (3) teachers who are trained in the subject and have taught it for not less than five years could attempt mentioning four objectives of the subject. Four (4) teachers also could not mention the objectives of Social Studies because they were not taught or learned them. These findings could be a result of teachers managing the subject in the classroom in most of the Senior High Schools in Ghana. This suggests that most teachers are not aware of the overriding purpose of the subject and therefore, might only be guided by past WAEC questions in their lesson delivery which may not lead to the achievement of the general objectives of the subject.

\subsection{Social Studies Teachers' Knowledge of Instructional Techniques and Methods}

The findings on teachers' knowledge on Social Studies instructional techniques indicated that among the varied instructional techniques, the common techniques most Social Studies teachers adopt for lesson presentation on contemporary issues to address societal challenges are the lecture, discussion, questions and answers techniques. Twenty-eight (28) teachers out of the thirty-two (32) teachers selected for the study, mentioned discussion, questions and answers as an instructional techniques they use, but could not specify whether whole class or small group discussion. Presumably, they were referring to the whole-class discussion. Nine of the teachers preferred and used lecture and whole-class dis- 
cussions because of the limited time to cover the syllabus before WASSCE and the jam-packed nature of the classrooms. Three teachers said they were not using self-directed instructional techniques because some of the learners enrolled in Senior High Schools these days are not academically inclined or good; so, the discussion and lecture techniques to them are the appropriate techniques that can help them cover their topics fast before WASSCE. It was also shown from the findings that what some of the teachers mentioned during the interview session as their preferred techniques for lesson delivery was at variance with the techniques they used during their teaching in the classroom.

\subsection{How Social Studies Teachers Use Instructional Techniques to Achieve the General Objectives of the Subject}

It was revealed from the findings that some of the Social Studies teachers especially the out-of-field teachers teach the subject without having in mind the instructional techniques to be used in class to achieve the general objectives of Social Studies in a given topic or unit. Eight (8) teachers observed used whole-class discussion, lecture, questions and answers techniques to deliver their lessons on contemporary issues in Social Studies. During the observation session, only two (2) of the teachers were observed using role-play as a technique to deliver his lesson. The use of whole-class discussion was blamed on the limited time and the jam-packed nature of the classrooms. The researcher observed that the observed teachers' discussions were teacher dominated and little was done by the learners.

\section{Conclusions}

Base on the findings and discussions made, some conclusions have been made from the study:

1) Among the teachers in the Senior High Schools selected for study, all of them possessed the minimum requirement for teaching Social Studies in Senior High Schools in Ghana. Also, twenty-two (22) of the teachers also lacked professional qualification or training for teaching of Social Studies. For the researcher, Out-of-field teaching seems to pose serious threats to the achievement of the general objectives of the subject. The objectives of Social Studies can be achieved if teachers who are professionally trained in the subject are recruited to teach it.

2) Teachers sampled for the study indicated that twenty (25) of them have never attended in-service training in Social Studies. This affects teachers' effective delivery in their lessons and denies them the opportunity of upgrading and updating their content and pedagogical skills in the teaching of Social Studies.

3) Since six (6) teachers observed did not conclude or evaluate their learners at the end of their lessons to ascertain the achievement of the objectives of their lessons Vis-à-vis the general objectives of the subject, this implies that majority of Social Studies teachers in Senior High Schools in Ghana are not interested in assessing the affective aspect of the subject which is the heart of Social Studies education. Lesson closure or evaluation enables teachers to know if the behavioural objectives formulated for the lesson have been achieved [10]. 
4) For teachers' knowledge of instructional techniques in Social Studies, twenty-eight (28) out of the (32) teachers sampled for the study could only mention instructional techniques such as lecture, questioning, and answers, discussions as techniques of Social Studies. These techniques they mentioned do not allow learners to develop critical thinking skills and the acquisition of positive attitudes and values. This indicated that most of the pedagogical practices they were taught in their institutions of practice were not utilized in the field of work or forgotten. Teachers sampled for the study claimed they use these techniques mentioned above for convenience and timely completion of the syllabus. Some teachers also said they are the most appropriate, because the current caliber of learners SHS is enrolled from JHS these days.

5) On teachers' use of instructional techniques, it was established from the study that teachers used lecture, discussions, questions and answers techniques in teaching Social Studies. If the achievement of Social Studies objectives is to be effective, the teacher must be well-versed in the use of a variety of teaching techniques [5].

6) Besides, it was realized that all the teachers the researcher observed did not put the learners in problematic situations for them to grapple with to find solutions to them or relate lessons with current issues in society. It is, therefore, possible that most of the Social Studies classrooms in the Senior High Schools are preoccupied with the teaching of superficial information relating to the various topics rather than using the classroom as a theatre for solving real social issues which seems to be the heartbeat of the subject. This could also be a reason for which many learners see the subject as boring.

\section{Recommendations}

Having discussed the various issues of the research findings, the following recommendations are put forward:

1) Since there are Out-of-field teachers in the senior high schools in Ghana teaching Social Studies, it is recommended that Ghana Education Service (GES) in collaboration with the Ministry of Education pay much attention to the professional training or qualification as the basis for Social Studies teachers to be recruited to teach Social Studies in Senior High School. This will help in the achievement of the general objectives of the subject. [34] attested to this when he pointed out that out-of-field teaching is a serious problem.

2) Since twenty-five (25) of the teachers could not mention the general objectives of Social Studies clearly, it is recommended that Ghana Education Service and Heads of Senior High Schools should give opportunity to teachers who are trained in the subject and have taught it long years to enroll in professional programmes mounted by Universities to update their knowledge and skill in teaching; more importantly instructional practices of Social Studies. This will improve Social Studies teachers' effectiveness in the delivery of their lessons; thereby achieving the general objectives of Social Studies. 
3) Since twenty-five (25) of the teachers said they have never attended in-service training on instructional techniques, it is recommended that Ghana Education Service should organize regular in-service courses in the form of seminars and workshops for teachers teaching Social Studies in all Senior High Schools in Ghana; thereby improving their classroom practices and making them more focused on the achievement of the objectives of the subject.

4) On-campus and off-campus teaching practices in various Universities should be intensified by allowing in-field lecturers to supervise the teacher-trainees to ensure the best practices in Social Studies. A situation where teacher-trainees during their on-campus teaching are made to teach lessons for less than thirty minutes is woefully inadequate to equip them with the best instructional practices in Social Studies. The on-campus teaching practice should help teacher-trainees to be well equipped with the objectives and instructional techniques of Social Studies so that they can teach to adequately address issues in society.

\section{Shortcomings of the Study}

This study considered Social Studies teachers' instructional techniques knowledge and use in achieving the general objectives of the subject. This study did not look at how these knowledge and use of instructional techniques by teachers of the subject will impact on learners' who are the beneficiary of teaching. The study was not also able to cover more regions and schools. The researcher therefore, suggests that future researchers should consider covering more regions and schools and further research on Social Studies teachers' instructional techniques knowledge impact on learners in Senior High School in Ghana.

\section{Conflicts of Interest}

The authors declare no conflicts of interest regarding the publication of this paper.

\section{References}

[1] Lawal, M.B. (2002) Citizenship Education: A General Study Text for Tertiary Institutions. Leo Prints, Lagos.

[2] Adeyemi, M.B. and Adeyinka, A.A. (2003) The Principles and Content of African Traditional Education. Educational Philosophy and Theory, 35, 425-440. https://doi.org/10.1111/1469-5812.00039

[3] Ayaaba, D.A., Eshun, I. and Bordoh, A. (2014) Achieving the Citizenship Education Goal of the Social Studies Curriculum in Ghanaian Senior High Schools: Challenges and the Way forward. Open Science Journal of Education, 2, 61-65.

[4] Akhtar, S. (2008) The Implementation of Education for Citizenship in Scotland: Recommendation of Approaches for Effective Practice.

http://www.sagepub.com/content/11/1/33 https://doi.org/10.1177/1365480207086752

[5] Tamakloe, E.K., Amedahe, F.K. and Atta, E.T. (2005) Principles and Methods of Teaching. Ghana Universities Press, Accra. 
[6] Ayaaba, D.A. and Odumah, L. (2013) Skills \& Techniques of Teaching Social Studies. 2nd Edition, Salt \& Light Publishing, Dansoman Estates.

[7] Dynneson, T.L. and Gross, R.E. (1999) Designing Effective Instruction for Secondary Social Studies. 2nd Edition, Prentice Hall Inc., Upper Saddle River, NJ.

[8] Savage, T.V. and Armstrong, D.G. (2000) Effective Teaching in Elementary Social Studies. 4th Edition, Prentice Hall Inc., Upper Saddle River, NJ.

[9] Ananga, E.D. and Ayaaba, D. (2004) Social Studies, Educating Effective Citizens. Asante and Hittscher Printing Press Ltd., Dansoman.

[10] Adam, M., Odumah, K.L. and Ngaaso, K.C. (2018) Skills, Methods, and Techniques of teaching Social Studies. Whitespace Gh., Accra, Ghana.

[11] Tamakloe, E.K. (2008) Issues in Social Studies Education. 2nd Edition, Ghana University Press, Accra.

[12] Chiodo, J. and Byford, J. (2006) Do They Dislike Social Studies? A Study of Middle School and High School Students. The Journal of Social Studies Research, 28, 16-26.

[13] Byford, J. and Russell, W. (2006) Analyzing Public Issues-Clarification through Discussion: A Case Study of Social Studies Teachers. Social Studies Review, 46, 70-72.

[14] Banks, J.A. (1985) Teaching Strategies for the Social Studies: Inquiry Valuing Decision-Making. Longman, New York.

[15] Quartey, S.M. (1984) Social Studies and Its Implications for Teaching and Evaluation. University of Lagos Press, Lagos.

[16] Russell, W.B. and Waters, S. (2010) Instructional Methods for Social Studies: A Survey of What Middle School Students Like or Dislike about Social Studies Instruction. Journal for the Liberal Arts and Sciences, 14, 1-4. https://doi.org/10.18546/HERJ.14.1.12

[17] Aggarwal, J.C. (2002) Teaching Social Studies. A Practical Approach. Vikas Publishing House PVT Ltd., New Delhi.

[18] Creswell, J.W. (2009) Research Design: Qualitative, Quantitative, and Mixed Methods Approach. 3rd Edition, Sage, Thousand Oaks, CA.

[19] Rocco, T.S., Bliss, L.A., Gallagher, S. and Pérez-Prado, A. (2003) Taking the Next Step: Mixed Methods Research in Organizational Systems. Information Technology, Learning, and Performance Journal, 21, 19-29.

[20] Adzahllie-Mensah, V., Agordah, E.F. and Gyamfuaa-Abrefa, M. (2017) Understanding Research. University of Education Press, Winneba.

[21] Creswell, J. W. (2014) Research Design: Qualitative and Mixed Methods Approach. 4th Edition, SAGE Publication Inc., Thousand Oaks, CA.

[22] Cooper, D.R. and Schindler, P.S. (2001) Business Research Methods. 7th Edition, McGraw-Hill, Inc., New York.

[23] Cozby, P.C. (2003) Methods in Behavioral Research. 7th Edition, McGraw Hill, Inc., New York.

[24] Frankel, J.R. and Wallen, N.E. (2000) How to Design and Evaluate Research in Education. McGraw-Hill, Companies, Inc., New York.

[25] Strauss, A. and Corbin, J. (1990) Basics of Qualitative Research: Grounded Theory Procedures and Techniques. Sage, Newbury Park, CA.

[26] Kumekpor, T.K. (2000) Research Methods and Techniques of Social Research. Sonlife Press \& Services, Accra.

[27] Kwabia, K. (2006) Theory in Social Research. The Link between Literature and Ob- 
servation. Production Unit, UWI, Accra.

[28] Schostak, J. (2006) Interviewing and Representation in Qualitative Research. Open University Press, Maidenhead.

[29] Adler, P.A. and Adler, P. (1998) Observational Techniques in Collecting and Interpreting Quantitative Materials. Sage Publications Inc., Thousand Oaks, CA.

[30] Seale, C. (2004) Qualitative Research Practice. SAGE, London. https://doi.org/10.4135/9781848608191

[31] Kumar, R. (1999) Research Methodology: A Step-by-Step Guide for Beginners. Sage Publications, New Delhi.

[32] Cohen, L., Manion, L. and Morison, K. (2007) Research Methods in Education. 6th Edition, Routledge, London.

[33] Ingersoll, R. (2003) Out-of-Field Teaching and the Limits of Teacher Policy. Report of the Center for the Study of Teaching and Policy and The Consortium for Policy Research in Education, 1-32. https://doi.org/10.1037/e383132004-001

[34] Ingersoll, R. (1999) The Problem of Underqualified Teachers in American Secondary Schools. Educational Research, 28, 26-37. https://doi.org/10.3102/0013189X028002026 